\title{
Ethical and Methodological Challenges for a Lawyer Facing Fieldwork Amidst the Working Poor
}

\author{
Desafíos éticos y metodológicos que enfrenta un abogado al realizar \\ trabajo de campo con trabajadores vulnerables \\ Desafios éticos e metodológicos que enfrenta um advogado no trabalho \\ de campo com trabalhadores em situação de pobreza
}

\author{
LAUra Porras SANTANiLla*
}

RECEPTION DATE: JANUARY 25, 2019. ApProval DATE: MARCH 27, 2019

Doi: http://dx.doi.org/10.12804/revistas.urosario.edu.co/sociojuridicos/a.7627

To quote this article: Porras, L. (2019). Ethical and methodological challenges for a lawyer facing fieldwork amidst the working poor. Estudios Socio-Jurídicos, 21(2), 107-134. Doi: http://dx.doi.org/10.12804/revistas.urosario.edu. co/sociojuridicos/a.7627

\begin{abstract}
In this paper, I will reflect on six different challenges that I had to face as a Colombian lawyer who conducted eighteen months of ethnographic fieldwork with poor workers in the localities of Ciudad Bolivar and Suba in Bogota. Specifically, I will reflect on the topics of accessing a new field, being an outsider, dealing with personal characteristics that influence data collection (such as gender and age), working under psychologically and physically overwhelming circumstances, dealing with the risk of confirming negative stereotypes about vulnerable populations, and doing interdisciplinary work. In doing so, I will engage and build on the literature published by scholars from different disciplines who explore in different ways the difficulties they encountered while conducting fieldwork with vulnerable populations. Ultimately, my goal is also to encourage lawyers who work addressing social problems and pursue an academic career, to take the time and risk to conduct the rewarding adventure of fieldwork.
\end{abstract}

Keywords: Ethnographic fieldwork, poor workers, labor law, qualitative methods.

* Lawyer with specialization in public management and master in Law from Los Andes University. PhD in Law from the University of Ottawa. Professor of law at El Rosario University. E-mail: laura.porras@urosario.edu.co. ORCID - http://orcid.org/0000-0001-8146-6934. The content of this paper is based on part of my unpublished $\mathrm{PhD}$ dissertation (Porras, 2018). 


\section{RESUMEN}

En este documento reflexionaré sobre seis desafíos que enfrenté como abogada colombiana al realizar dieciocho meses de trabajo de campo etnográfico con trabajadores pobres en las localidades de Ciudad Bolívar y Suba en Bogotá. Específicamente, reflexionaré sobre el reto que implica acceder a un nuevo campo de estudio, provenir de un lugar distinto en el espacio social en relación con la población estudiada, entender que las características personales de quien realiza el trabajo de campo (como el género y la edad) influyen en la recolección de datos, trabajar bajo circunstancias abrumadoras tanto física como psicológicamente, enfrentar el riesgo de confirmar estereotipos negativos sobre poblaciones particularmente vulnerables, y por último, hacer trabajo interdisciplinario. Para el efecto, discutire y aportaré a la literatura publicada por académicos de diferentes disciplinas, que han reflexionado sobre los retos y las dificultades que implica el trabajo de campo con poblaciones vulnerables. En última instancia, mi objetivo también es animar a los abogados que trabajan con problemas sociales en mente y que quieren seguir una carrera académica, para que asuman el riesgo de embarcarse en la gratificante aventura del trabajo de campo.

Palabras clave: etnografía, trabajadores pobres, derecho laboral, métodos cualitativos.

\section{RESUMO}

Neste documento irei refletir sobre seis desafios que enfrentei como advogada colombiana ao realizar dezoito messes de trabalho de campo etnográfico com trabalhadores pobres nas localidades de Ciudad Bolívar e Suba em Bogotá. Especificamente, refletirei sobre o desafio que implica aceder a um novo campo de estudo, provir de um lugar distinto no espaço social em relação com a população estudada, entender as características pessoais de quem realiza o trabalho de campo (como o gênero e a idade) influem na recolecção de dados, trabalhar sob circunstâncias esmagadoras tanto física quanto psicologicamente, enfrentar o risco de confirmar estereótipos negativos sobre populações particularmente vulneráveis, e por último, fazer trabalho interdisciplinar. Para este efeito, discutirei e aportarei à literatura publicada por acadêmicos de diferentes disciplinas, que têm refletido sobre os desafios e as dificuldades que implica o trabalho de campo com populações vulneráveis. Em última instância, meu objetivo também é animar aos advogados que trabalham com problemas sociais em mente e que querem seguir uma carreira acadêmica, para que assumam o risco de embarcar-se na gratificante aventura do trabalho de campo.

Palavras-chave: etnografia, trabalhadores pobres, direito laboral, métodos qualitativos. 


\section{Introduction}

It is not easy to find papers written by Colombian scholars that reflect on the theoretical and methodological challenges that arise when conducting fieldwork. In particular, it is difficult to find papers written by lawyers. As part of my doctoral dissertation, I conducted eighteen months of ethnographic fieldwork with poor workers in Bogota (September 2012 to January 2014), in an effort to target and characterize the social grouping to whom the most vulnerable segment of the working poor belong, and to analyze how both State and non-State legal regimes interact to influence their productive strategies. In this paper, I will reflect on six different challenges that I had to face while conducting fieldwork. I will do so by engaging and building on the scholarly literature published by authors who explore in different ways the difficulties they encountered while conducting fieldwork with vulnerable populations. Amongst them, I will cite scholars from different disciplines such as Pierre Bourdieu, Philippe Bourgois, Adrienne Pine, Mitchell Duneier, Russell Bernard, Christina Clark-Kazak, Daniel Goldstein, Uzma Jamil, Shahaduz Zaman, Laura Nader, Susan Thomson, An Ansoms, Jude Murison, Elisabeth Wood, Joan Cassell, Nancy Scheper-Hughes, Peggy Golde, Carol Warren, Kathleen Dewalt, Gloria Ladson-Billings, and Jun Li.

The six challenges I will discuss are accessing a new field, being an outsider, dealing with personal characteristics that influence data collection, working under psychologically and physically overwhelming circumstances, dealing with the risk of confirming negative stereotypes about vulnerable populations, and doing interdisciplinary work. Firstly, I will reflect on the challenge of accessing a new field. As the poor have every reason to be cautious, it is difficult to get in, establish long-term relationships based on trust, and get to ask difficult questions. More particularly, I will consider the issue of how to deal with distrust, as well as with managing participants' expectations when studying people who expect much more than what the researcher can provide in return. Secondly, I will weigh in the challenge of being an outsider. The researcher is clearly an outsider when coming from a different country, social class or ethnicity. Even though I shared the origin of the people I studied (we were born in the same homeland), differences in cultural, economic, and social capital can be so profound, 
that one is never more than a partial-insider. As Bourdieu (1990) argues, when the researcher is situated in a different place within the social space, entering a new field can be the equivalent of learning a new language.

Thirdly, I will discuss the challenge of dealing with the way that personal characteristics influence data collection. It is recognized that personal characteristics such as gender, age, and marital status, amongst others, influence how the researcher is perceived, which therefore affects data collection. In my case, being a woman with no children (at the time), married (at the time), and other personal characteristics, both allowed and limited my access to certain information, and influenced the way I perceived others. Fourthly, I will reflect upon the challenge of working under psychologically and physically overwhelming circumstances, since the context in which I worked affected what I was able to document empirically. For instance, I will address how witnessing different perpetuated types of violence against the poor affected me and my work. Fifthly, I will discuss the risk of confirming negative stereotypes about vulnerable populations. It has to do with Laura Nader's (1972) old warning "don't study the poor and powerless because everything you say about them will be used against them" (p. 18). I acknowledge the risk, but I refuse it from an ethical as well as an analytical perspective to sanitize the poor. In my opinion, to envision real solutions, we need full descriptions. Finally, I will discuss the challenge of doing interdisciplinary work. Engaging with other disciplines and using methodologies that I was never trained as a lawyer to apply felt like opening 'black boxes.' It also complicated the issue of finding a legal audience. In the rest of the paper, I will address the six challenges in detail, and then I will end with some concluding remarks.

\section{Accessing the field}

Ethnographic fieldwork is a powerful technique that can be particularly useful to document the lives of the vulnerable in a society that is hostile to them. However, as they have every reason to be cautious, it is difficult to get in, establish long-term relationships based on trust, and get to ask difficult questions. Philippe Bourgois (2003) managed to live for five years in one of the poorest tenements of El Barrio while writing In search of respect: 
selling crack in El Barrio, but to do that, he had to violate what he called the "racial and class-based apartheid in America." Adrianne Pine traveled to Honduras for different periods of time during six years to conduct a multisite ethnography that could give her some answers about precarious labor and male alcoholism, but as an upper-middle class white woman, writing Working hard, drinking hard: on violence and survival in Honduras turned out to be a profoundly life-changing experience (Pine, 2008). As difficult as it was, both authors acknowledge that long-term ethnographic fieldwork allowed them to collect data in thousands of intrusive acts and reduced the problem of reactivity. Since the analytical tension in both books focuses on how individuals deal with the forces that oppress them, lower reactivity on the part of the participants was a key factor to assess how honest they were about their thoughts and actions, and ultimately how valid the collected data was. Nevertheless, it was not easy, for neither of them, to get in.

As stated in the introduction, my goal was to target and characterize the social grouping to whom the most vulnerable segment of the working poor in Bogota belongs. More specifically, I wanted to study people that worked on the street. While it could have been easier for me to be introduced by public officials who worked or interacted with, for example, street vendors, I did not want to be associated with the State nor with anyone who could hold power over them. Fortunately, with the help of some acquaintances and former colleagues, I managed to be introduced to two different groups of street vendors by local political activists of a faction of the left called MOIR (Independent and Revolutionary Workers Movement). Participants located in the neighborhood San Francisco of Ciudad Bolivar. After being introduced, I proposed a simple deal to the vendors: if they allowed me to spend time with them, they would have free legal advice whenever they needed it. It didn't take long for me to understand how useful I was, and to quickly build rapport. It also did not take long for me to realize that I wanted to expand my study group, and after using chain referral methods (basically snowball sampling ${ }^{1}$ ), I started

1 Snowball is a network sampling method for studying hard to find or hard to study populations. Following the snowball technique, a small number of people in a population is located and asked to recommend others with whom to work. The researcher moves from informant to informant, and the sampling frame grows with each encounter (Russell Bernard, 2011). 
working with other poor workers such as sex workers and recyclers. I later grouped all those workers under the category street rebuscadores ${ }^{2}$ and focused my observations in two of the poorest areas of Bogota-Ciudad Bolivar (in the neighborhoods of San Francisco and Sierra Morena) and Suba (in the neighborhoods of Rincón and Lisboa)-.

Offering free legal services turned out to be a big challenge. I had never worked so hard as a lawyer before in my life. I was stunned by the diversity and number of legal activities I actually performed. I helped regularize a neighborhood that had been invaded by a group of settlers (most of them, street rebuscadores) 20 years ago; I assisted them to comply with the procedure required to request the installation of public utilities (such as gas and electricity) in their homes; I filed health-related tutelas as street rebuscadores were denied medicines and medical procedures; I gave legal advice regarding family issues (domestic violence, child support, alimony, and divorce); I helped create a non-profit foundation to support sports activities for teenagers; I helped tenants who had been asked to return the space where they performed their productive activities without economic compensation after having accumulated a significant number of customers; I aided women get a place for their children in public schools, and I gave advice regarding criminal procedures whether street rebuscadores were victims of crime or perpetrators themselves. ${ }^{3}$ As challenging as it was, offering free legal services was a key move to build trust since many street rebuscadores were not willing to spend time with me to help me write a dissertation. For instance, the first day I met German (a street vendor), he told me:

2 In the past I have written other papers where I refer to street rebuscadores to address other issues not included in this paper (See, for example, Porras 2019.) Street rebuscadores share the following five common characteristics: 1) they identify themselves as self-employed or family workers; 2 ) they conduct their work mainly in the street or other public spaces; 3 ) they report that this work occupies most of their time; 4) they are affiliated to the subsidized health care system, and 5) their highest educational degree (if obtained) is high school. In big numbers, I am talking approximately about 82000 people in Bogotá and 818000 people in Colombia (DANE, 2015).

3 I wrote in my field notes that I had never studied and learned so much law: "Almost every person who approaches me has a legal question. It is now that I realize the importance of social capital. Without my social networks, without my friends and acquaintances, there is no way I could have given legal advice regarding so many different issues in a fairly reasonable way." 
I once met a lady who said she was going to write a dissertation about people like us, so I gave her a lot of information. She told me that she was going to come for at least a couple of months but after a couple of days I never saw her again in my life. I guess it was not easy for her to smell poverty (no le gustaría el olor de la pobreza). I would never do that again, but at least she didn't get us excited by offering something in return. So, forgive me if I ask [...] but, what kind of person[...] what kind of lawyer offers legal advice for free? What do you get in return?

Although I tried to explain as carefully as I could the value that 'information,' 'just information,' 'plane information' about their productive strategies represented to me, many thought there had to be something more and it took me a long time to earn their trust. At the end of my fieldwork German told me:

Honest to God Laurita, it took me time to trust youl...] you know that. I thought you were a government spy or something like that[...] like in the movies. Ha, Ha, Ha! Then, I thought you were one of those rich girls who lost her path with drugs or alcohol or stuff and was expiating her sins by helping us $\mathrm{Ha}, \mathrm{Ha}, \mathrm{Ha}, \mathrm{Ha}$ ! (We both laughed). Then[...] since Oswaldo said so many times that it had to do with your political positions, I thought you were going to run for office or something. Nowadays, I'm just grateful to God for your friendship and for all your help. You fell from the sky Laurita, you really did. I hope you quote me in that book. I hope you feel I was somehow useful for you[...] Ok[...] let's stop this little chat because we are getting all emotional and stuff.

It speaks of the issues of managing expectations and the responsibility of researchers conducting this type of work. Christina Clark-Kazak (2013) worked with young Congolese refugees settled in Kampala and reflects upon the importance of managing research participants' expectations in urban areas with vulnerable populations who expect much more than what the researcher can provide in return. In fact, managing expectations can be one of the biggest if not the biggest challenge when working with vulnerable populations. Daniel Goldstein, for instance, starts his book: Owners of the Sidewalk: Security and Survival in the Informal City, reporting on the hard time he had facing the expectations of vendors in the Cancha 
mega-market in the city of Cochabamba (Bolivia). In the prologue to his book, he tells us the following story:

I explain to Don Silvio that I want to write a book about the lives of the ambulantes [...] Don Silvio is no fool: he is a market vendor, a shrewd capitalist who understands the value of commodities, including information [...] Don Silvio knows that he can grant me access to ambulantes, and he has something to ask of me in return: to build a market for the ambulantes [...] The likelihood of the ambulantes getting a market is infinitesimal. The costs would be too high, the real estate too scarce, the political pressure against it too great for such thing ever to come to pass [...] "Bueno" don Silvio says to me, returning to the business at hand. "How can you help"? (Goldstein, 2016, p. x-xii).

Goldstein's story makes clear that managing the expectations is something that requires more than our empathy. Clark-Kazak (2013) reminds us that our primary responsibility is to uphold the ethical imperative of doing no harm, and, if we can, to do some good for men and women who share so much of themselves with us in our pursuit of academic knowledge. But, how? She cautions against monetary compensation and highlights the need to ensure that research relationships do not become extractive and exploitative. As I offered free legal help, I felt no pressure to provide my informants with more. However, especially at the beginning of my fieldwork, some informants asked me for money to have lunch or to pay for some other daily needs. I decided that I was not going to give them money unless I faced an extreme situation (it happened only once when the daughter of a sex worker needed a medicine). Over time, they stopped asking me for money. In fact, the day arrived when they invited me to have lunch. I registered that moment in my field notes:

I was deeply moved today. I traveled downtown with Martha, Patricia and Isadio (all street vendors) and we had lunch in San Victorino. Lunch was very cheap for my standards (3.500 pesos/ US 1.1 of 2019). We had soup, rice, potatoes, plantain, salad, a piece of meat and juice. When I was going to pay, they said they wanted to invite me. I refused, but they told me that people from the block (the other street vendors in San Francisco - Ciudad Bolívar) had given them money to invite me to 
have lunch in a fancy place downtown. I was very grateful. I later realized that no one had asked me for money in a very long time.

I accepted their invitation as a symbol of friendship, gratefulness, and respect. It felt like they trusted me. Building rapport is tremendously satisfying in personal terms, but it is also fundamental for academic purposes because there is no other way in which the researcher can capture and theorize subtle processes hidden from the naked eye. For instance, it was only because Bourgois got to spend so much time with his characters, that he could explain why it was so difficult for his acquaintances in El Barrio to achieve working-class stability. It was not so much that they could not find a job (as difficult as that was), but that it was very difficult for them to keep it. ${ }^{4}$ Time and trust were also vital for me to be able to answer a number of difficult questions such as: Why is the entrepreneurship discourse so successful with street rebuscadores? What kind of structural factors constrains their "choice" to work in the street? Why do they have large families? What type of economic role do families play in their lives? What types of practical skills are needed to become a street rebuscador? Can anyone become one? Does feeling like second-class citizens have an impact on their productive strategies?

\section{Being an outsider}

The researcher is clearly an outsider when coming from a different country. This was Bourgois' (2001) case, for example, when he studied revolutionary peasants in El Salvador, or Pine's (2008) when studying drunks and maquilas in Honduras. However, even when the ethnographer researches people who share her or his origin, as Bourgois (2003) did when he studied the crack dealers in El Barrio-New York or Duneier (1999) did when he studied street vendors in Greenwich Village-New York. Differences in class, education, and race can be so profound, that

4 According to Bourgois (2003), "Obedience to the norms of office-culture (where jobs were more likely to be available), was in "direct contradiction to street culture's definitions of personal dignity - especially for males who were not socialized to accept public subordination," much less to accept orders from women (p. 115). 
one is never more than a partial-insider because those differences can outweigh the cultural identity associated with being born in the same place. Uzma Jamil, for instance, was born in Pakistan and raised by upper-class Pakistani parents. Nevertheless, she was schooled and lived her whole life in Canada. Not surprisingly, the poor Pakistanis with whom she worked in Montreal felt like foreigners to her. She concludes that her research evidenced the dislocation inherent to her status (Jamil, 2007 , p. 218). Even in the case of an investigator whose nativity can be thought as twofold -as in Shahaduz Zaman's case-, he admits he does not know everything about his own society. Being Bangladeshi and having worked as a doctor in the Bangladeshi hospital where he later conducted fieldwork, Zaman acknowledges that his status reduced the cognitive and emotional effort required to understand a foreign culture. Still, he felt he was not a "complete member" of the community, not only because he had not been a doctor for many years, but because researching the daily life of "others" creates a distance. He, therefore, characterizes his work as one performed by both "an insider and an outsider in the hospital world" (Zaman, 2008, p. 145).

I was born in a working middle-class family. My mother worked as a schoolteacher and my father as a University professor all their lives. Their income depended exclusively on their work, as well as the well-being of some of their closest relatives. However, being an only child, they managed to save enough money to pay for the highest quality of education available in Colombia, only to the wealthy. Therefore, the difference in cultural capital between street rebuscadores with whom I conducted fieldwork and myself was considerable. In bare numbers, most of them were part of the bottom $23.3 \%$ of the Colombian population who did not finish high school, while I was part of the upper 3.3\% who completed a master's degree at the time (DANE, 2015). ${ }^{5}$ Differences in economic capital were also considerable, although not as considerable as cultural capital. At first sight, I was part of the wealthiest $2.3 \%$ of the population living in Bogota, while they were part of the poorest $9.1 \%$ (Secretaria Distrital de

5 In 2015, only five per million inhabitants in Colombia had completed a PhD. See: http://noticias.universia.net.co/actualidad/noticia/2015/01/14/1118167/colombia-formasolo-5-doctores-cada-millon-habitantes.html 
Planeacion de Bogota [SDP], 2013). Notwithstanding, my starting salary as a University professor in Colombia was only around three to five times higher as compared to the monthly income of the average street rebuscador. Differences in economic capital were considerable, but I think it is interesting to highlight that both street rebuscadores and I perceived our differences in cultural capital as deeper. At the end of my fieldwork, for instance, Isadio (street vendor) stated:

I've never met someone like you Laurita. Honest to God. You have studied all your life. All your life! And still, you work for nothing. If I had as much study as you have I would be living the great life. Fuck the rest of the world... the great life! As soon as you get tired, and start thinking about some real money, just call me. We could sell avocados and you could make at least twice what they are paying you right now. La vida da muchas vueltas (life takes many turns). Let's wait and see what happens if you have children. If you do, and I hope you do, maybe you will feel real pressure and you will start using that brain and all that study to make some real money.

Differences in economic and cultural capital suggest that street rebuscadores and I situate in very different places within the social space. As Bourdieu (1998) argues, social space is constructed in such a way that agents or groups are distributed in it according to their position in statistical distributions, based on two principles of differentiation: Economic capital and cultural capital. Differences in our total amounts and composition of capital can also explain those in the location of the physical space we occupy in Bogota. As in many Latin American cities, spacial segregation in Bogota is very high and mostly associated with income status. In contrast, globally it is associated primarily with racial groups, ethnicity or religion (Greenstein, Sabatini E Smolka, 2000). ${ }^{6}$ In Bogota, there are at least two types of segregation within the city: By choice of rich individuals in some areas, and forced, segregation of

6 That is not to say that there is no overlap between social status and other variables such as race or ethnicity in Colombia as elsewhere. In fact, there is a growing literature in the field of intersectionality studies applied to different areas (See, for example, Esguerra E Bello, 2014; Viveros, 2016). 
poor ones due to lack of opportunities in other parts of the city (Bogliacino, Jiménez \& Reyes, 2015). Recent studies using the hedonic pricing method show that Bogotá has very high segregation levels (SDP \& Universidad Nacional de Colombia [UNAL], 2013). Not surprisingly, most street rebuscadores I befriended carried out their activities in parts of the city where I had never been before (although I have lived in Bogota all my life) and vice-versa. We do not share acquaintances or social networks. Since, as Bourdieu (1998) argues, the space of social positions is retranslated into a space of position-takings through the mediation of the space of dispositions or habitus, I can safely conclude that street rebuscadores and I have very different habitus, or in other words, we are not united by a relationship of homology (diversity within homogeneity) which means that we are likely to have considerable differences in our interests and world views.

And indeed, there were many differences. Getting close to street rebuscadores and understanding what they were saying was, in fact, equivalent to the learning of a new language. As Bourdieu (1990) argues, someone can not enter a new field by an instantaneous decision of the will, but nor by previously knowing its language or by engaging in a slow process of co-option and initiation which is equivalent to the learning of a new language. Although I was born in Bogota, I have spent most of my time in the city, and I look physically similar to street rebuscadores-I do not belong to a different racial or ethnical group, and nothing in my physic seems foreign, it was evident to everyone around that I was a stranger. The way I talked-my words and rhythm, how I smelled "like someone who doesn't sweat," Isadio once said, as well as my clothes (less colorful, better fabrics and usually clean) were clear differentiating factors.

Of course, being born in Bogota reduced the cognitive and emotional effort required to understand street rebuscadores. I ' $k$ new' them in a way, maybe the way an urban citizen 'knows' the peasants of their own country. Plus, we spoke the 'same' Spanish. However, the fact that we were situated in to very different places within the social space was enough to make us feel like foreigners who needed to get to know each other. For me, it meant that I had to learn to eat their food, drink their water, and learn when to talk, be silent, and keep my distance. It was 
not easy. Small everyday ordinary details made it difficult. For instance, many demonstrated their generosity by offering coffee. Their coffee, nevertheless, is usually made with a lot of sugar and with water, which sometimes (especially at the beginning) made me sick. Plus, I tried to avoid their bathrooms as much as I could because I found their smell disturbing and drinking coffee did not help. Therefore, I drank their coffee until I learned excuses that were allowed within their habitus such as 'I'm trying to get pregnant and I heard that drinking coffee doesn't help' when in fact I was not trying to get pregnant at the time, and I was completely unaware of any kind of relationship between coffee and fertility.

\section{Being a woman with no children (at the time), married (at the time), and other personal characteristics that influenced fieldwork}

It is known that the researcher's personal characteristics such as gender, age, and marital status influence data collection (Scheper-Hughes, 1983; Golde, 1986; Warren, 1988; Dewalt \& Dewalt, 2002; Ladson-Billings, 2003; Russell Bernard, 2011; Li, 2008). Russell Bernard (2011) argues, for instance, that personal characteristics might limit access to certain information, and also influence how you perceive others. For example, "in all cultures, you can't ask people certain questions because you're a [woman] [man]. You can't go into certain areas and situations because you're a [woman] [man]. You can't watch this or report on that because you're a [woman] [man]" (p. 281). That is not to deny that gender is a negotiated idea: "what you can and can't do if you are a man or a woman is more fixed in some cultures than in others, and in all cultures there is lots of individual variation in gender roles" (Bernard, 2011, p. 281). The point, I believe, is that researchers confront not only their personal limitations but also those imposed on them by the culture they study. During an informal conversation at the end of my fieldwork, for example, I had the opportunity of reflecting upon the issue of how my personal characteristics influenced the way the community saw me with two of my main informants:

Laura: "So... what do you think helped me to get to know you?" 
Isadio (street vendor): "You never looked threatening, you were nice from the beginning... and you looked strong. Small, but strong [he laughs]. I knew that you were a tiger and that you could help us..."

Laura: "But why didn't I look threatening? Was it the way I looked? The way I approached you? The fact that I'm a woman?

Patricia (street vendor): "I think that being a woman helped. For me, at least, it made a difference. It was easy talking to you; I could get you inside my kitchen with my children. I prefer talking to women... it's like... like we understand each other."

Laura: "And you Isadio... did it make a difference for you?

Isadio: "What... that you are a woman?"

Laura: "Yeah"

Isadio: "No... not really. I guess I never saw you as a woman the laughs]. You are not someone who's finding a way every minute of the day to screw our lives [he laughs again]. You just look like a good person Laurita, and there are still good people in this world. There's no more to it, so stop trying to split hairs in two (no le trate de buscar 5 patas al gato). I trusted my gut, and my gut told me I could trust you. I guess the street teaches you to trust your gut."

As a female researcher participating in women's daily activities, I can say that gender matters in this study. It did not only make a difference for Patricia but for many other women including little girls who felt they could talk to me about sensitive issues such as sexual violence. I had easy access, and they did not perceive me as threatening to them. This gender advantage in field research supports the idea that in order to understand women's life situations and experiences more studies should be conducted by women and for women (Ettorre, 1989). Being a woman also made a difference with men. I understand Isadio's words 'I never saw you as a woman' as 'I never sexualized you.' However, I have no doubt that the fact that I am a woman mediated the way he approached me. If I had been a man, maybe he would have had the opportunity to talk about issues he found interesting, but felt would have been inappropriate to discuss with a woman. ${ }^{7}$

\footnotetext{
7 Russell recalls an interesting experience related to the impact that differences in sex have when conducting fieldwork: "Sara Quandt, Beverly Morris, and Kathleen DeWalt spent months investigating the nutritional strategies of the elderly in two rural Kentucky counties. According to DeWalt, the three women researchers spent months, interviewing key informants, and never
} 
Finally, I was not only a woman but a woman with 'lots of time' (according to their standards) because I had no children at the time, I was middle-aged and married. As Thomson, Ansoms, and Murison (2013) argue that as a researcher we are a 'plurality of selves' combining aspects of gender, race, nationality, sexual orientation, marital status, age, cultural background, and so on. Age matters, they did not perceive me as too young to be immature, or too old to be unable to help them with their physically exhausting daily activities. Being married mattered because it was the perfect excuse to leave before it was dark, as well as to put an end to unwanted sexual advances before they even started. Being a parent would have also helped me to talk to people about specific areas of life and get more information. As Joan Cassell (1987) says, children are a "guarantee of good intentions" (p. 281), plus they are always good conversation openers. Throughout the research process, however, my role, position, and identity changed. After fieldwork was over, I got divorced and gave birth to two children. I was no longer collecting data, but I still visited my main informants from time to time (and they visited me). Being divorced and a mother made me closer to the women I befriended as never before. They felt (and I also did) that I could finally understand them. ${ }^{8}$ Had I the chance to start all over again, I would write a different dissertation focusing mainly on the struggles and the experience of those women who taught me so much and who completely changed me.

\section{Working under psychologically and physically overwhelming circumstances}

Working under psychologically and physically overwhelming circumstances is a real challenge and can be dangerous. In Working hard,

turned up a word about the use of alcohol. 'One day'... the research team traveled to Central County with Jorge Uquillas, an Ecuadorian sociologist who wanted to visit the Kentucky field sites. As soon as one of their informants saw him, he asked him 'are you a drinking man?' Over the next hour the informant gave all type of useful information that female researchers could not access before." (DeWalt, DeWalt \& Wayland, 1998, p. 280).

8 The opposite happened to Nancie González in the 1980s. For her, being a divorced mother of two young sons in the Dominican Republic was very difficult: "Had I to do it again I,she says,] I would invent widowhood with appropriate rings and photographs" (González, 1986, p. 92). 
drinking hard, Adrienne Pine chose to study alcohol and not drugs because it was supposed to protect her; still, she had to overcome different overwhelming circumstances (such as the death of all the gang-members she interviewed), and to confront difficult events where physical violence was present. When Bourgois wrote In search of respect, selling crack in El Barrio, in New York, his life was not only constantly in danger, but the "whirlpool of suffering" around him sometimes just devastated him. Furthermore, the personal cost he paid was very high. In the preface to his book, he apologizes to his ex-wife for imposing so much anxiety on her for so many years, and adds: "I hope that is not one of the reasons we are no longer together, because if it is, I regret it profoundly" (Bourgois, 2003, p. xv).

Before I started my $\mathrm{PhD}$, I worked reconstructing facts and analyzing massacres related to the internal armed conflict in the Grupo de Memoria Histórica. I was used to working under difficult circumstances but was emotionally tired. Since the internal armed conflict took place mostly in rural areas, studying poverty in Bogota seemed a good way to get away, at least, from war-related violence. I was aware that studying poverty within the city meant in all probability that I was going to have to deal with both structural ${ }^{9}$ and symbolic violence, ${ }^{10}$ but it was less clear for me whether war-related violence was present and in what way. However, reading Bourgois (2001) made me think that Bogota situates itself in a sort of intermediate limbo, where both the violence of war and peace coexist. In The power of violence in war and peace, Bourgois concludes that the ramifications of terror in a civil war are much more complex than he originally thought. Political violence meshes with structural and symbolic violence, reverberating in what he calls a dynamic of "everyday violence," which is a violence of the same kind that he observed as a result of the fusing of structural and symbolic violence during peacetime in East Harlem. In other words, according to Bourgois, both in times of war and peace, the fusion of either political/structural/symbolic or

9 By 'structural violence,' I am referring to "the political-economic organization of society that imposes conditions of physical and emotional distress, from high morbidity and mortality rates to poverty and abusive working conditions" on the poor (Bourgois, 2001, p. 7).

10 By 'symbolic violence,' I refer to the imposition of an ideology, which legitimates and naturalizes the status quo on subordinated groups (Bourdieu \& Wacquant, 1992). 
structural/symbolic violence against the poor result in patterns of persistent everyday violence and daily human suffering.

As soon as I started fieldwork, it became clear to me that I was researching in a context where structural/symbolic and war-related violence resulted in different forms of everyday violence. For instance, not long after I arrived in Ciudad Bolivar, the teenage daughter of a street vendor was raped by the owner of the storage room where she kept her vending cart and some of the products she sold. She told me that her daughter was raped because she was ill and could not afford to pay the fee of the storage room for quite some time. A combination of material misery meshed with and fueled by gender power relations produced and naturalized that kind of everyday violence against women. I later learned that the perpetrator was supposed to be part of a 'demobilized' paramilitary group, which explained why no one was taking the risk of initiating either legal or illegal actions against him. Thus, the shadow of war-related violence was present and continued to be present during my fieldwork.

The context in which I worked affected what I was able to document empirically. I was subjected to stressful situations and it was often impossible for me to have the peace of mind I needed to gather data for my dissertation. However, drawing from the methodology Duneier used when he wrote Sidewalk (Duneier, 1999), I had a recorder running all the time. After my fieldwork was over and I heard the audio recordings, I realized that there was a lot of information I had missed while being in a 'survival mode' by which I mean the conscious and unconscious psychological effects that witnessing different types of violence perpetuated against the poor caused in me. I was in 'survival mode' when women, especially young girls, shared stories of sexual violence, when I helped to take care of ill rebuscadores, when babies were left home alone because their mothers had to work to buy milk, when I shared a plate of food in a freezing 'house' full of leaks while being told that they were a blessing because through them you could see the stars at night. I was also in 'survival mode' when their and my personal integrity were at risk; when they fought against each other, during violent encounters with the police, when we heard gun shots and it was not safe to leave. I often wrote in my field notes that I felt devastated, that I was tired. I remember arriving home, closing the door and literarily sitting on my kitchen floor to finally 
eat something while I cried. Every day of fieldwork was a day knowing and exploring my own limitations, of learning how to keep going in the middle of circumstances that I could not control in any possible way.

In short, fieldwork was an experience that confronted me with my limits and stretched my capacities. Thomson, Ansoms, and Murison (2013) argue that in violent contexts "research is a series of positive and negative emotions - delight, frustration, anxiety, joy, anger, relief, panic and sadness, to name but a few- that will be experienced daily" (p. 3). Larissa Begley - quoted by Thomson and his colleagues- writes about the emotional pitfalls of working in northern Rwanda and offers essential advice: "we must recognise that our experience of these extreme emotions is just the tip of the iceberg compared with what our research subjects feel every day" (Thomson, Ansoms \& Murison, 2013, p. 6). I found some comfort in the fact that my work made sense (at least to me) and could have an impact, even if minimal. Plus, I came to believe that for many of the people I interviewed, sharing their life story was some sort of additional service that I provided in the course of my research (Wood, 2006). At the end of my fieldwork, for instance, a female rebuscadora told me:

Thanks for listening to me mamita. It was nice talking to you. I honestly don't want to read your book... you know that. And I'm grateful for all that legal advice, although I still think that we are alone and that the law is not on our side (que estamos solos y que la Ley no está de nuestro lado). But... you know? Thanks for listening to me. No one had listened to me before. That made a difference. That will stay with me.

\section{Dealing with the risk of confirming negative stereotypes about vulnerable populations}

There is an ethical problem when a researcher is dealing with vulnerable individuals. If one believes that structural forces (abusive working conditions, classism, physical and emotional distress, patriarchy, etc.) affect the lives of the poor, one should be aware that the effects of those forces do not usually look good. However, exposing them creates the risk that unfriendly readers (especially those who believe firmly in individual responsibility and failure) find evidence to confirm their negative stereo- 
types against the poor. Both Bourgois (2003) and Pine (2008) acknowledge the problem in their ethnographies with vulnerable individuals, and both refuse from an ethical as well as analytical perspective to sanitize the poor. Pine (2008) guards herself against a voyeuristic celebration of gangs and drunks by offering a sympathetic reading of the suffering she witnessed (p.31). Bourgois (2003) reflects at length on the matter and clearly states that sanitizing the poor would make him complicit of oppression. For instance, he believes he couldn't have avoided the description of how some of his characters participated in a gang rape, because failure to address sexual violence would have only reinforced the sexist status quo (p. 208). If human action reproduces to some extent the given social and cultural order, and if structural, symbolic and sometimes political violence constantly inflicts itself in that order, then it is only logical that the product will not look pretty. Regardless, in their opinion, if one believes that structural forces affect poor individuals' lives, then the effects should be described as they are.

I share that conviction, and in my work, I have tried to describe the lives of vulnerable individuals as I perceived them. I was first confronted to this issue when I worked with the Grupo de Memoria Historica and we discussed if some information that could affect the image of victims of massacres should be excluded from the reports. I was against those exclusions because I thought they contributed to the false stereotype of portraying victims as 'pure' and perpetrators as 'evil' in a highly degraded conflict. Later, when I started working with street rebuscadores and perceiving their lack of attachment to the community, their "negative individualism" (Mendoza, 2011, p. 123), their lack of solidarity, the violence of all sorts they inflict upon themselves but also upon the most vulnerable within the community, I was confronted with the same issue all over again. However, I came to the conclusion that I was going to describe the lives of the vulnerable as I perceived them because to envision real solutions we need full descriptions.

Let me give what I think is a good example of why I don't believe that sanitizing the poor is good for the poor. Some scholars like Coraggio (2012) argue that there is an increasing number of poor workers in Latin America who oppose capitalist thought by creating forms of self-employment based on relations of solidarity, reciprocity, and cooperation but 
not on capitalist relations. Their conclusions are based on very specific examples of groups of poor workers who joined efforts after moments of massive political or economic crises (hyperinflation, dictatorships) or on the experiences of minority groups with very specific cosmogonies (indigenous communities, highly ideologized workers), but not on the experiences of the traditionally marginalized and atomized majority of the working poor. However, in my opinion, Coraggio and some of his followers tend to generalize marginal cases giving the false impression that there is massive resistance against traditional capitalist thought from below. I acknowledge their good intentions and even dream with the world they envision, but I think that idealizing the poor is not good for the poor because in the best case scenario it only pushes us away from finding real solutions. Consequently, I believe that studies should avoid at any cost the voyeuristic celebration of the survival strategies of the poor, who are full of anxiety, unpredictability, lack of trust, and sometimes anger. As Wilkinson (2008) writes, "both as social scientists and as human beings, we have the responsibility to "tell I as it happened," rather than how we would have liked it to be" (p. 60). Ultimately, as Bourgois (2003) argued "the problem and the responsibility is also in the eyes of the beholder" (p. 18).

\section{Doing interdisciplinary work and finding a legal audience}

I found it challenging to engage in interdisciplinary research, most particularly, in debates in which lawyers had not been particularly active. To answer the research questions guiding my dissertation, I had to engage in debates that have been developed mainly by economists and sociologists from different political perspectives using different methodologies. For instance, I had to learn about informality, rebusque, social classes, as well as different quantitative and qualitative methodologies, amongst others. Since legal scholarship and education in Latin America has been largely dogmatic, abstract and extremely formal, legal scholars have rarely engaged in those discussions, or when they do, they do it without the intention of approaching them from an interdisciplinary point of view or in depth. In fact, many lawyers approach other disciplines as a sort 
of 'black box.' Latour (1999) defines black boxing as "the way scientific and technical work is made invisible by its own success. When a machine runs efficiently, when a matter of fact is settled, one need focus only on its inputs and outputs and not on its internal complexity" (p. 304). Lawyers are not usually interested in taking the time to understand the internal workings of other successful disciplines, their technicalities, and limit themselves to playing the 'role of the lawyer' when approaching a particular problem. The reverse is also true. For instance, Sylvestre, Damon, Blomley, and Bellot (2015) argue that all critical scholars should care about the technicalities of legal knowledge "because it has political and ethical consequences" (p. 1351). The call is to try to understand the internal workings of a given system by diving into overlooked rationalities attached to 'technical' practices and processes. Often, contested hypothesis turn into accepted results, which then translates into a 'black-box.' When that happens, the hypothesis is no longer open for debate because a determinate scientific community has accepted it.

Since I was interested in the technicalities as well as in the way politics influence the approach of scholars from other disciplines to different research questions, I had to deal with both the challenge of engaging with a sophisticated literature whose epistemological bases was largely unknown to me and with finding scholars from other disciplines (most particularly economists and sociologists) who were interested in teaching me and discussing the questions that gradually came to me during my fieldwork. For instance, when trying to understand one of the main debates related to informality-why is informality so high (and increasing) across the developing world? I was not only interested in the 'lawyers part' (the way regulation has an impact upon informality rates), but also in the technicalities of the debate (I learned about labor market performance, impact of wage and non-wage costs, rigidities, etc.), and in the different answers scholars offered depending on their political views (for instance, differences in how neoclassical and interventionist scholars approach the technicalities of the debate to arrive at different conclusions). Yet, it was difficult to find scholars from other disciplines who were willing to help me open the 'black box' in order to be able to engage in interdisciplinary work. Searching the internet, I was lucky to find a few research groups that existed in Colombia, and that met to discuss issues related 
to my research questions. I contacted them and attended some of their discussion groups. Without their help, explanations, and good advice, interdisciplinary work would have been impossible.

It was also challenging to use both quantitative and qualitative methodologies that have not been traditionally used by lawyers. In my $\mathrm{PhD}$ dissertation, I used both quantitative methods (applying different statistical techniques) and qualitative methods to answer my research questions. As a lawyer, I was never trained to apply quantitative or qualitative methodologies, which meant I had to open another sort of 'black box.' Actually, when I was going to start my fieldwork members of the legal academic community in Bogota advised me not to do it because I lacked the proper training. However, I had two strengths. Unlike most lawyers, I like numbers (which helped with quantitative methodologies), maybe because my father was a nuclear physicist and I studied mathematics, as a hobby, for some time. Furthermore, when I worked at the Grupo de Memoria Histórica, I had the opportunity of observing and learning from some of the best social scientists in the country to conduct interviews and participant observation, which greatly helped with qualitative methodologies. Plus, I took a graduate course of methodology in the department of anthropology as my elective course in the $\mathrm{PhD}$ program. Therefore, I was willing to take the risk, ask the questions, learn, and make mistakes. While I enjoy being a lawyer, I believe that a researcher should use all available tools to approach complex social problems and particularly that lawyers ought to take more risks and open more black boxes' especially within the framework of a doctoral dissertation.

Finally, it was challenging to find a legal advisor for my work. Most lawyers in Colombia do not engage in interdisciplinary work. There are many reasons that might explain this, but let me highlight only two: most law schools are still attached to a version and understanding of the law, in which the professor/litigant occupies a central position while the professor/researcher, a marginal one. Furthermore, research costs time and money. Most law schools demand their professors to publish at least two or three times a year (no time) and have very limited budgets to fund research (no money). Therefore, law professors share more incentives to publish traditional analysis of rules, cases or legal theory (less time, less money). Additionally, legal scholarship has been attached to traditional 
distinctions between different 'areas' of the law (such as constitutional law, administrative law, or labor law), while interdisciplinary research usually starts with a social problem in mind. For instance, the community I studied for my PhD dissertation was made up of workers, but to analyze how the law affected their productive strategies I could not limit myself to studying labor law which is supposed to be the area of law that studies workers. For different reasons that I discussed elsewhere (Porras, 2019), labor law rarely influences the productive strategies of street rebuscadores, so I had to study other areas of law such as constitutional law and police law to be able to answer my research questions. In other words, if the legal researcher has social problems in mind, law areas become extremely porous.

However, deciding not to engage in a more traditional analysis not frameable within a specific area of the law, has its costs. Many people that study a PhD want to stay in academia. Nevertheless, professor positions in Colombia are scarce and usually framed within traditional areas of law. Untraditional $\mathrm{PhD}$ dissertations usually lack an immediate legal audience, and it is more likely that the author will have a hard time finding a job. For instance, I wrote a dissertation about the lives and legal challenges of a group of workers (labor law?), but my immediate audience was not made up of labor lawyers. In fact, it took months (almost a year!) to interest labor lawyers in my work. My immediate audience was made up of a very small part of the local legal community which is not related to traditional legal analysis, and which is willing to address the study of complex social problems. However, due to the particularities of the Colombian context, progressive and socio-legal scholars work primarily with violence, gender issues, migration, mining, land, amongst others, but not necessarily with poverty, subsistence, and urban livelihoods. In other words, they were interested in my methodological and even my theoretical background, but not on the specific topic of my dissertation. Paradoxically for me, it was easier to find a legal audience interested in my work outside of Colombia. Maybe, that was one of the most important reasons why I ended up studying my $\mathrm{PhD}$ in Canada. However, it also meant writing a dissertation full of street quotations in English, which implied an additional challenge. After my fieldwork was over, I went through most of the audio recordings and transcribed in Spanish only 
the bits and pieces that I wanted to quote. I then translated all selected to English, which turned out to be overwhelming. While complaining about translation, a friend of mine told me something I will never forget. He told me it was not only a problem of translating Spanish to English or even street Spanish to English. It was a problem of translating Ciudad Bolivar and Suba to English.

\section{Final remarks}

I will end up asking a question with no obvious answer: Why should Colombian lawyers interested in an academic career insist on doing fieldwork in spite of the fact that it implies different ethical and methodological challenges, it takes time, it costs money, and it makes it difficult to get in and advance in an academic career? Citing María Victoria Uribe, a great anthropologist, teacher, and friend, conducting fieldwork "changes your perspective and opens your eyes." For instance, systems of labor regulation were built with the proletariat in mind. The proletariat consists of mostly industrial workers, for whom labor regulation regarding stability, routes of advancement, fixed hours, unionization, etc. makes sense. Despite that those workers constitute a minority in Colombia, labor lawyers associate the proletariat with the working poor. However, the truth is that within the informal sector, the majority of informal workers are not wage-earners but rather self-employed workers (Porras 2018). That means that the working class in Colombia basically constituted itself from self-employed poor workers and not form employed industrial workers (the proletariat). Why labor lawyers, in general, do not acknowledge the existence of self-employed poor workers that constitute the majority of the working class population? The reason, I think, is that although we work addressing social problems, we rarely take the time to observe the reality that surrounds us. Conducting fieldwork, in a way or another, is a great way to make visible, first to us, and then to others, a reality that can be right outside our window. 


\section{References}

Bogliacino, F., Jiménez, L. \& Reyes, D. (2015). Identifying the effect of the socio-economic stratification on urban segregation in Bogota. Retrieved from https://ssrn. com/abstract $=2714907$

Bourdieu, P. \& Wacquant, L. (1992). An invitation to reflexive sociology. Chicago, IL: University of Chicago Press.

Bourdieu, P. (1990). The logic of practice (R. Nice, Trans.). Stanford, CA: Stanford University Press.

Bourdieu, P. (1998). Practical reason: On the theory of action. Stanford, CA: Stanford University Press.

Bourgois, P. (2001). The power of violence in war and peace: Post-Cold War lessons from El Salvador. Ethnography, 2(1), 5-34.

Bourgois, P. (2003). In search of respect: Selling crack in El Barrio. New York: Cambridge University Press.

Cassell, J. (Ed.). (1987). Children in the field. Philadelphia: Temple University Press.

Clark-Kazak, C. R. (2013). Research as "social work" in Kampala? Managing expectations, compensation and relationships in research with unassisted, urban refugees from the Democratic Republic of Congo. In S. Thomson, A. Ansoms, \& J. Murison (Eds.), Emotional and ethical challenges for field research in Africa. The story behind the findings (pp. 96-106). London: Palgrave Macmillan.

Coraggio, J. L. (2012). La economía social y solidaria (ESS) en América latina. In A. Guillén \& M. Phélan (Eds.), Construyendo el buen vivir (pp. 236-256). Cuenca: Universidad de Cuenca/PYDLOS.

Colombia, Departamento Nacional de Estadísticas (DANE). (2015). Gran Encuesta Integrada de Hogares - GEIH.

Dewalt, K. M. E Dewalt, B. R. (2002). Participant observation: A guide for fieldworkers. New York: AltaMira Press.

Duneier, M. (1999). Sidewalk. New York: Farrar, Straus and Giroux.

Esguerra, C. \& Bello, J. A. (2014). Interseccionalidad y políticas públicas LGBTQ en Colombia: usos y desplazamientos de una noción crítica. Revista de Estudios Sociales, (49), 19-32. Retrieved from https://res.uniandes.edu.co/view. php/907/index.php?id=907

Ettorre, B. (1989). Women and substance use/abuse: Towards a feminist perspective or how to make dust fly. Women's Studies International Forum, 12, 593-602.

Golde, P. (1986). Women in the field. Anthropoligical experiences. Berkeley: University of California Press. 
Goldstein, D. M. (2016). Owners of the sidewalk: Security and survival in the informal city. Durham: Duke University Press Books.

Gonzalez, N. (1986). The anthropoligist as female head of Household. In T. L. Whitehead \& M. E. Conaway (Eds.), Self, sex and gender in cross-cultural fieldwork (pp. 84-102). Urbana: University of Illinois Press.

Greenstein, R., Sabatini, F. E Smolka, M. O. (2000, noviembre). Segregación espacial urbana. Fuerzas, consecuencias y respuestas normativas. Retrieved from https://www.lincolninst.edu/publications/articles/segregacion-espacial-urbana

Jamil, U. (2007). The stranger within: Rethinking distance and proximity of researcher as community member. In A. Williamson \& R. de Souza (Eds.), Researching with communities: Grounded perspectives on engaging communities in research (pp. 209-218). London: Muddy Creek Press.

Ladson-Billings, G. (2003). Racialized discourses and ethic epistemologics. In N. K. Denzin E Y. S. Lincoln (Eds.), The landscape of qualitative research: Theories and issues (pp. 398-432). Thousand Oaks, CA: Sage.

Latour, B. (1999). Pandora's hope: Essays on the reality of science studies. Cambridge: Harvard University Press.

Li, J. (2008). Ethical challenges in participant observation: A reflection on ethnographic fieldwork. The Qualitative Report, 13(1), 100-115. Retrieved from http://nsuworks.nova.edu/tqr/vol13/iss1/8/

Mendoza, P. (2011). Del arte de "rebuscar" o del nuevo rostro de los trabajadores. Revista Colombiana de Sociología, 34(2), 121-136. Retrieved from https://revistas.unal.edu.co/index.php/recs/article/view/27821/28064

Nader, L. (1972). Law in culture and society. Chicago, Aldine.

Pine, A. (2008). Working hard, drinking hard. On violence and survival in Honduras. California: University of California Press.

Porras, L. (2018). "Viviendo del rebusque:" A study of how law affects street rebuscadores in Bogotá. (Doctoral dissertation). Ottawa University, Ottawa, Canada.

Porras, L. (2019). The limits of state labour law: its inability to protect street rebuscadores in Bogotá. Revista de Antropología y Sociología: VIRAJES, 20(2).

Russell Bernard, H. (2011). Research methods in anthropology: Qualitative and quantitative approaches. Lanham: AltaMira Press.

Scheper-Hughes, N. (1983). The problem of bias in androcentric and feminist anthropology. Women's Studies, 10, 109-116. 
Bogota, Secretaria Distrital de Planeación (SDP) - Universidad Nacional de Colombia (UNAL). (2013). Segregación socioeconómica en el espacio urbano de Bogotá. Retrieved from http://www.sdp.gov.co/transparencia/informacion-interes/ otras-publicaciones/segregacion-socioeconomica-espacio-urbano-de-bogota

Sylvestre, M. E., Damon, W., Blomley N. G Bellot, C. (2015). Spatial tactis in criminal courts and the politics of legal tecnicalities. Antipode, 47(5), 1346-1366.

Thomson, S., Ansoms, A. \& Murison, J. (Eds.). (2013). Emotional and ethical challenges for field research in Africa. The story behind the findings. Houndmills: Palgrave Macmillan.

Viveros. M. (2016). La interseccionalidad: una aproximación situada a la dominación. Debate Feminista, 52, 1-17. Doi: 10.1016/j.df.2016.09.005

Warren, C. (1988). Gender issues in field research. Newbury Park, CA: Sage.

Wilkinson, C. (2008). Positioning security and securing one's position: the researcher's role in investigating security in Kyrgyzstan. In C. R. L. Wall \& P. P. Mollinga (Eds.), Field work in difficult environments: discussing the divergence between theory and practice (pp. 43-67). Berlin: Lit Verlag.

Wood, E. J. (2006). The ethical challenges of field research in conflict zones. Special issue: Political Ethnography I, 29, 373-386. Doi: 10.1007/s 11133-006-9027-8

Zaman, S. (2008). Native among the Natives physician anthropologist doing hospital ethnography at home. Journal of Contemporary Ethnography, 37(2), 135-154. Doi: 10.1177/0891241607312495 